\title{
Antioxidant Activity of Entrapped alfa-tocopherol and Lutein in PLGA Nanoparticles in Wistar Rats
}

\begin{abstract}
DANIELA MIRICESCU11, ALEXANDRA TOTAN**, IULIA IOANA STANESCU1*, ANDREEA DIDILESCU², RUXANDRA SFEATCU4, ANA MARIA ALEXANDRA STANESCU ${ }^{5}$, CONSTANTIN STEFANI ${ }^{3}$, MARIA GREABU ${ }^{1}$

'University of Medicine and Pharmacy Carol Davila, Faculty of Dental Medicine, Department of Biochemistry, 8 Eroii Sanitari Blvd, 050474, Bucharest, Romania

2University of Medicine and Pharmacy Carol Davila, Faculty of Dental Medicine, Department of Embriology, 8 Eroii Sanitari Blvd, 050474, Bucharest, Romania

${ }^{3}$ University of Medicine and Pharmacy Carol Davila, Faculty of General Medicine, Department of Family Medicine, 8 Eroii Sanitari Blvd, 050474, Bucharest, Romania

${ }^{4}$ University of Medicine and Pharmacy Carol Davila, Faculty of Dental Medicine, Department of Oral Health and Community Dentistry, 8 Eroii Sanitari Blvd, 050474, Bucharest, Romania

5University of Medicine and Pharmacy Carol Davila, Faculty of General Medicine, 8 Eroii Sanitari Blvd, 050474, Bucharest, Romania

The hypercaloric diet leads to obesity which is a risk factor for developing many systemic diseases such as diabetes, cardiovascular diseases and cancer. The purpose of our study was to observe the antioxidants effects of entrapped alfa-tocopherol (vitamin E) and lutein in Poly Lactic-CO-Glycolic acid (PLGA) in Wistar rats that received 3 weeks hypercaloric diet. Hepatic and splenic lysates have been used to detect changes in total antioxidant capacity (TAC) and advanced oxidative protein products (AOPP). The AOPP liver levels were statistically decreased in the case of rats groups that received a daily dose of PLGA-lutein or PLGAvitamin $E$ versus the control group. The AOPP level was decreased but statistically insignificant in Wistar rats spleen who received a daily dose of PLGA-Iutein. Athepatic level, TAC was statistically increased in rats groups that received a daily dose of vitamin E or lutein. An increased statistical level of TAC was observed in the spleen cell lysing in Wistar rats who received the daily dose of PLGA-vitamin E. Entrapment of vitamin $E$ and lutein in PLGA structure has diminished the effects of hypercaloric diet and can be considered a attractive and promising approach to enhance the bioavailability and activity of poorly water soluble compounds.
\end{abstract}

Keywords: PLGA nanoparticles, vitamin E, lutein, hypercaloric diet

According to World Health Organization (WHO) more than 41 million children up to 5 years old are obese, over 340 million children and adolescents aged 5-19 years are overweight and over 650 million of the adult population is obese [1].

High fat saturated diets, refined carbohydrates, sedentary lifestyle, low consumption of fruits and vegetables in the diet leads to obesity. Obesity is a major health problem for the population around the world, the epidemiological studies made so far show an alarming increase of obese people three times higher than in the 1980s (children and adult population) [2].

Obesity is a risk factor for the development of cardiovascular diseases, type 2 diabetes, metabolic syndrome, and many cancers associated with endocrine disorders: breast, endometrial, ovarian, thyroid and prostate. Another consequence of the hypercaloric diet is the nonalcoholic fatty liver that has grown heavily in the adult population around the world [2,3].

Obesity is associated with oxidative stress (OS) observed by decreasing antioxidants, increased levels of oxidized lipids, hyperglycemia, chronic inflammation, hyperleptinemia, increased production of reactive oxygen species (ROS) at the endothelial level [4].

Abdominal obesity, hypertension, dyslipidemia are characteristics of metabolic syndrome, a common disorder commonly found in the adult population, associated with sedentary life and unhealthy diet [5]. It has been already observed in many studies the effects of vitamin $E$ as potential interventional treatmentfor metabolic syndrome, due to its anti-obesity, anti-hypercholesterolemic, antidiabetic, anti-hypertensive effects [5-7].

Lutein is a carotenoid belonging to the xanthophyll family that is synthesized by plants, assimilated by the human body only by diet, concentrated in the eye, butalso presenting an antioxidant role for the for the entire body. Vitamin $\mathrm{E}$ and lutein are hydrophobic compounds, so their absorption rate by the human body is low $[8,9]$.

These inconveniences have been removed by entrapment of vitamin $E$ and lutein into the structure of nanoparticles such as PLGA. These nanoparticles are made up of lactic acid and glycolic acid, are approved by US Food and Drug Administration (FDA) as carriers for different types of drugs in many experiential studies [10].

The main aim of our study was to observe the antioxidant effects of vitamin $E$ and lutein entrapped in PLGA nanoparticles in Wistar rats that received the hypercaloric diet for 3 weeks.

\section{Experimental part}

PLGA nanoparticles synthesis and characterization has already been described in one previously article Miricescu D 2017 [11].

-Animal model

The study included W istar rats divided into the following groups:

* email: alexandratotan99@gmail.com, Phone: 0722396324

The authors equally contribued to the present work iulia_stanescu@yahoo.com,Phone: 0724030069 
-Group 1 received the standard diet and a daily dose of nanoparticles PLGA (50 mg/kg body weight)

-Group 2 was the control group that received only standard diet

-Group 3: received the hypercaloric diet and a daily dose of PLGA- vitamin E nanoparticles (50 $\mathrm{mg} / \mathrm{kg}$ body weight)

-Group 4: received the hypercaloric diet and a daily dose of PLGA -lutein nanoparticles ( $50 \mathrm{mg} / \mathrm{kg}$ body w eight)

-Group 5: the control group that received only the hypercaloric diet (butter and sugar)

-Each group was consisted of 5 Wistar rats

The study was conducted over a 3-week period and PLGA-Vitamin E, PLGA-lutein have been administered by gavage. Wistar rats were obtained from Animal Facility of Carol Davila University of Medicine and Pharmacy, Bucharest, Romania and the experimental procedures were carried out under Convention 86/609/E.E.C. from November 24, 1986, for the Protection of Vertebrate Animals Used for Experimental and other Scientific Purposes. After 3 weeks of treatment, the rats of the five groups were sacrificed, liver and spleen were collected from each rat. The lysis of the two organs was performed using $25 \% \mathrm{KCl}$.

\section{Oxidative stress markers}

Advanced human oxidative protein (AOPP) levels were determined using the ELISA method (kits were provided by RND-Germany). ELISA microtiter plate is pre-coated with an antibody specific to AOPP. Standards and samples are added to the microtiter plate wells with a biotin-conjugated polyclonal antibody specific for AOPP. In the next step is added Avidin conjugated to Horseradish Peroxidase (HRP) to each microplate well and incubated. After the incubation period followed by 3 successive washes, the TMB substrate solution is added to each well. Only the wells that contain

\begin{tabular}{|l|l|l|}
\hline Parameter & TAC (U/g protein) & $\mathrm{p}$ \\
\hline $\begin{array}{l}\text { 1 Group 1(normal rats treated with } \\
\text { PLGA) }\end{array}$ & $117.83 \pm 9.41$ & 0.3 \\
\hline 2. Group 2 (control group) & $115.33 \pm 9.41$ & 0.3 \\
\hline $\begin{array}{l}\text { 3. Group 3 (rats treated with } \\
\text { hypercaloric diet + PLGA -Vitamin E }\end{array}$ & $101.33 \pm 9.86$ & 0.05 \\
\hline $\begin{array}{l}\text { 4.Group 4 (rats treated with } \\
\text { hypercaloric diet + PLGA -lutein) }\end{array}$ & $107.12 \pm 12.4$ & 0.05 \\
\hline $\begin{array}{l}\text { 5. Group 5 (rats treated only with } \\
\text { hypercaloric diet) }\end{array}$ & $88.33 \pm 12.4$ & 0.05 \\
\hline
\end{tabular}

\begin{tabular}{|l|l|l|}
\hline Parameters & TAC (U/g protein) & $\mathrm{p}$ \\
\hline $\begin{array}{l}\text { 1 Group 1 (normal rats treated with } \\
\text { PLGA) }\end{array}$ & $96.2 \pm 6.18$ & 0.2 \\
\hline 2. Group 2 (control group) & $92.6 \pm 6.18$ & 0.2 \\
\hline $\begin{array}{l}\text { 3. Group 3 (rats treated with } \\
\text { hypercaloric diet + PLGA -Vitamin E }\end{array}$ & $101.33 \pm 7.35$ & 0.06 \\
\hline $\begin{array}{l}\text { 4.Group 4 (rats treated with } \\
\text { hypercaloric diet + PLGA -lutein) }\end{array}$ & $94.00 \pm 3.54$ & 0.1 \\
\hline $\begin{array}{l}\text { 5. Group 5 (rats treated only with } \\
\text { hypercaloric diet) }\end{array}$ & $90.33 \pm 3.54$ & 0.06 \\
\hline
\end{tabular}

Table 2

THE MAIN VALUES FOR TAC FROM SPLEEN LYSATE
AOPP, biotin-conjugated antibody and enzyme-conjugated Avidin will exhibit a change in colour. Sulphuric acid is added to stop the enzyme-substrate reaction and the colour change is measured spectrophotometrically at a wavelength of $450 \mathrm{~nm}$.

Total antioxidant capacity or status (TAC/TAS) assay activity was performed using an analysis kit ( Randox, Crumlin, UK) , on a semiautomatic biochemistry analyser. The method is based on the ability of antioxidant molecules to quench the long-lived ABTS+, a blue -green chromophore with characteristic absorption at $734 \mathrm{~nm}$, in comparison to that of Trolox, a water-soluble vitamin E analogue.

\section{Statistical analysis}

Statistical analysis was performed using Student's t-test, statistical significance was set at a $p$-value of $<0.05$.

\section{Results and discussions}

The results of our study for TAC and AOPP are presented in Table 1,2,3 and 4.

The hypercaloric diet is associated with changes in glucose and lipid metabolism, e.g hyperglycemia induced pathways that will generate ROS and finally OS [12]. Advanced glycosylation end products binds to specific cell surface receptors and activate intracellular transcription nuclear factor NF-kB. This further activates protein kinase $C$, sorbitol and transcription of vascular cell adhesion molecules (VCAM) that will produce ROS. Increased glucose concentration actives polyol pathway, nicotinamide adenine dinucleotide phosphate (NADPH) is also activated and reduces glucose to sorbitol and superoxide anion is produced in the endothelium[12].
Table 1

THE MAIN VALUES FOR TAC FROM LIVER LYSATE 


\begin{tabular}{|l|l|l|}
\hline \multicolumn{1}{|c|}{ Parameter } & $\begin{array}{l}\text { AOPP }(\mu \mathrm{mol} / \mathrm{g} \\
\text { protein) }\end{array}$ & $\mathrm{p}$ \\
\hline $\begin{array}{l}\text { 1 Group 1 (normal rats treated with } \\
\text { PLGA) }\end{array}$ & $1.88 \pm 0.17$ & 0.4 \\
\hline 2. Group 2 (control group) & $1.86 \pm 0.17$ & 0.4 \\
\hline $\begin{array}{l}\text { 3. Group 3 (rats treated with } \\
\text { hypercaloric diet + PLGA -Vitamin E }\end{array}$ & $2.53 \pm 2.23$ & 0.002 \\
\hline $\begin{array}{l}\text { 4.Group 4 (rats treated with } \\
\text { hypercaloric diet + PLGA -lutein) }\end{array}$ & $2.56 \pm 2.22$ & 0.002 \\
\hline $\begin{array}{l}\text { 5. Group 5 (rats treated only with } \\
\text { hypercaloric diet) }\end{array}$ & $6.6 \pm 2.22$ & 0.002 \\
\hline
\end{tabular}

\begin{tabular}{|l|l|l|}
\hline Parameter & AOPP ( $\mu \mathrm{mol} / \mathrm{g}$ protein) & $\mathrm{p}$ \\
\hline $\begin{array}{l}\text { 1 Group 1 (normal rats treated with } \\
\text { PLGA) }\end{array}$ & $1.3 \pm 0.47$ & 0.001 \\
\hline 2. Group 2 (control group) & $2.06 \pm 0.47$ & 0.001 \\
\hline $\begin{array}{l}\text { 3. Group 3 (rats treated with } \\
\text { (already published) }\end{array}$ & $1.83 \pm 0.11$ & 0.009 \\
\hline $\begin{array}{l}\text { 4.Group 4 (rats treated with } \\
\text { hypercaloric diet + PLGA -lutein) }\end{array}$ & $1.86 \pm 0.10$ & 0.3 \\
\hline $\begin{array}{l}\text { 5. Group 5 (rats treated only with } \\
\text { hypercaloric diet) }\end{array}$ & $2.00 \pm 0.11$ & 0.009 \\
\hline
\end{tabular}

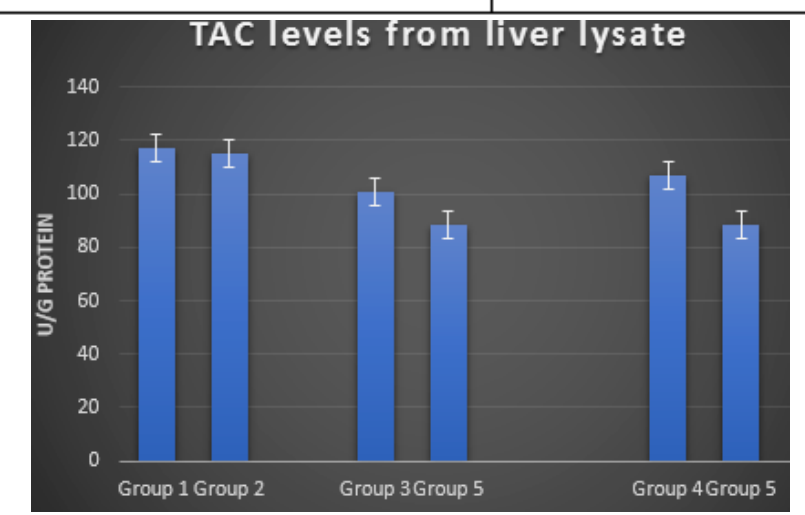

Fig. 1. Liver TAC levels

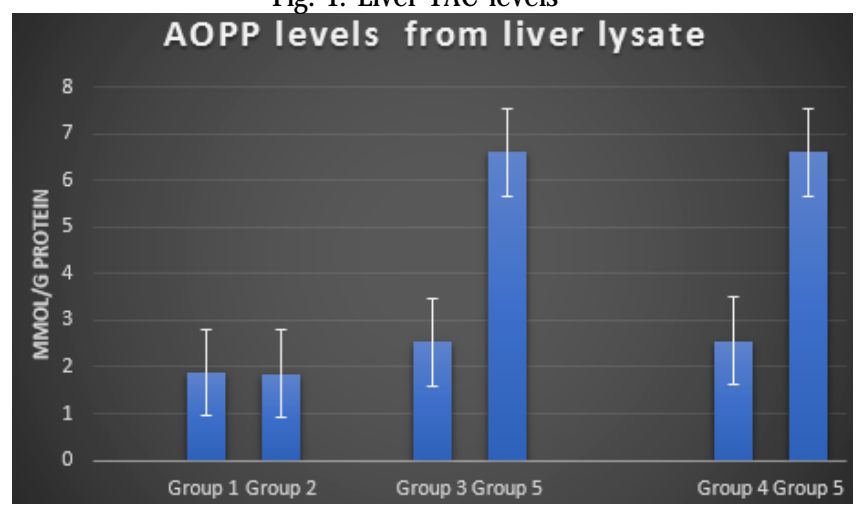

Fig. 2. Liver AOPP levels

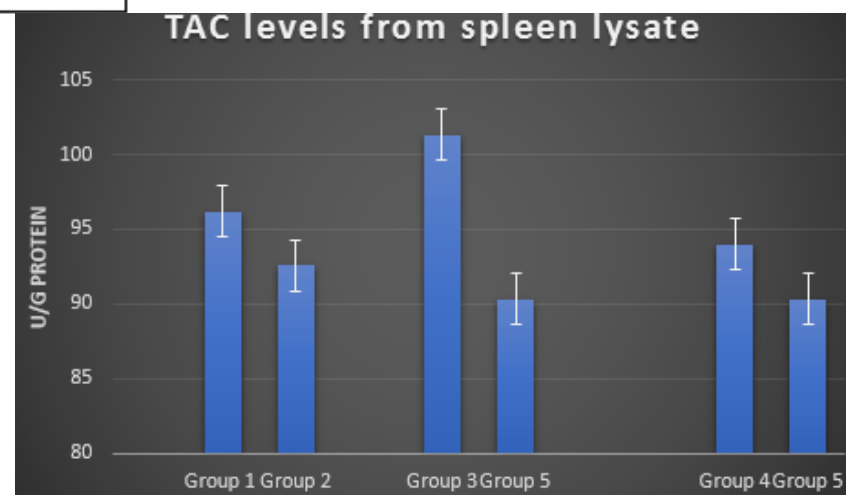

Fig. 3. Spleen TAC levels

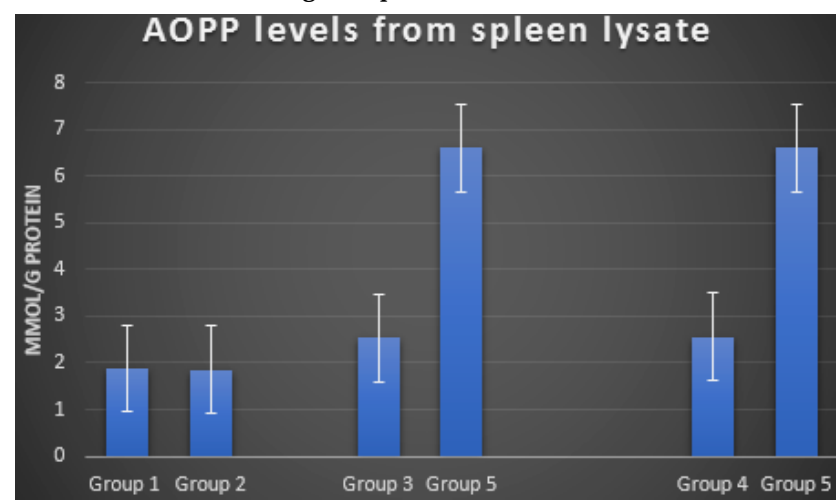

Fig. 4. Spleen AOPP levels

MATERIALE PLASTICE $\bullet 56$ No. $3 \bullet 2019$ 
Animal studies reported that body increased levels of sorbitol cause oxidative damage and activates stress genes. Hyperglycemia also induces glucose autooxidation and produces oxidants with reactivity similar to the hydroxyl radical, the most dangerous ROS capable of interacting with DNA [12-15].

Intracellular triglycerides synthesis caused by fat diet, will lead to superoxide anion increased production by suppressing the mitochondrial adenine nucleotide transporter $[16,18]$. Abdominal or visceral obesity is associated with a high plasma level of free fatty acids that will produce radicals derived from nitrogen in smooth vascular and endothelial cells by activating protein kinase C [19].

The lipids are used as substrates for oxidation, stimulate radical formation and finally contributes to the accumulation of oxidation products in adipose tissue, which may cause in the end thrombosis, endothelial dysfunction and atherosclerosis [18-21]. Dyslipidemic profile is characterized by increased levels of triglycerides, LDL, 4-hydroxyinonenal, malondialdehyde (MDA), low levels of HDL and antioxidants [21-25].

Obesity is associated with chronic inflammation, characterized by activation of pro-inflammatory cytokines such as IL-6, TNF- $\alpha$, which will activate the production of reactive $C$ protein (CRP). Elevated levels of TNF- $\alpha, I L-6$, $\mathrm{CRP}, \mathrm{NFkB}$, and NADPH activation, leads to the generation of ROS and finallyassociation of obesity with SO [26-28]. These molecular events will conduce to decreased levels of intracellular antioxidants such as superoxide dismutase (SOD), glutathione peroxidase (GPX), catalase (CAT), total antioxidant capacity (TAC) and glutathione (GSH). Antioxidant vitamins like $E, C, A, \alpha$ and $\beta$ carotenoids present decreased levels [26-29]. Childhood obesity is associated with increased serum levels of LDL, MDA, AOPP and decreased levels of antioxidant enzymes such as SOD, CAT, GPX and GSH [30,31].

Vitamin $E$ is currently considered a promising therapeutic agent for attenuating the negative effects of obesity. To observe vitamin E effects many studies have been carried out on obese, diabetic, hyperlipidemic or metabolic syndrome animals models. The results of this studies conducted between 4 and 28 weeks revealed a decrease in hyperglycaemia, dyslipidemia, but some studies did notreport changes of the mentioned parameters after daily oral administration of vitamin $E$ [5].

Lutein protects the human body against the free radicals that attack DNA [32]. Similar to vitamin E, lutein cannot reach its full potential to its poor bioavailability.

A method that will protect vitamin $E$ and lutein from oxidation and will improve their absorption into the cell are PLGA nanoparticles. The biodistribution of this nanoparticles formed by lactic and glycolic acids with minimal toxicity have been already tested in studies conducted on laboratory animals (mice and rats) or cell cultures [33, 34]. Adsorption, distribution, metabolism and excretion of the PLGA nanoparticles are determined by a number of properties such as size, charge, hydrophobicity and targeting molecules. Ingestion may be by oral or intravenous route, so depending on their size they can reach the liver, kidneys, spleen, heart, lungs and brain [33]. PLGA thathave between 140-200nm were accumulated mostly in kidneys and lungs, those smaller than $100 \mathrm{~nm}$ will be found in liver and spleen [33]. PLGA nanoparticles used in our study had 96 $\mathrm{nm}$ dimension.

In our previously published studies we have already noticed in Wistar rats that hypercaloric diet leads to OS highlighted by increasing the level of MDA and decreased of GSH level, both liver and spleen. Vitamin $\mathrm{E}$ and lutein restores hepatic and splenic redox status by reducing lipid peroxidation and increasing the level of intracellular GSH [35-37]. In the last part of our study on Wistar rats, we wanted to see if SO induced by the hypercaloric diet can cause protein oxidation.

A standard diet does not lead to a change in AOPP hepatic level between group 1 and 2, being statistically insignificant (Table 3). Interestingly, in spleen we achieved a decreased statistically level for group 1 versus group 2 (Table 4), which can be regarded as a protective effect of PLGA.

Statistically significant differences were obtained in hepatic lysate for Wistar rats who received hypercaloric diet. Group 5 presented an increased AOPP level compared with groups 3 and 4 (Table 3). Unfortunately the hypercaloric diet does not led only to carbohydrates or lipids oxidation, goes further and can also cause protein oxidation.

AOPPs are currently considered important and useful markers in protein oxidative damage, which are formed in early stages, are stable and easy to detect.

Statistic significantly decreased levels of AOPP were obtained at the hepatic level for groups 3 and 4 versus group 5. Vitamin $\mathrm{E}$ and lutein entrapped in PLGA enter the hepatocyte and protects them from ROS induced by hypercaloric diet (Table 3). By comparing the results we can see a stronger protective effect of vitamin $\mathrm{E}$ compared to lutein.

At the spleen level we detect a statistically decreased level for AOPP in group 3 versus group 5. Group 4 who received a daily dose of PLGA-lutein present a decreased level for AOPP but statistically insignificant compared with group 5. Administration of lutein and vitamin E to the spleen have produced similar effects.

In liver cell lysate obtained in rats treated with standard diet we detect an statistically insignificant increased level for TAC at group 1compared with group 2 (Table 1). Statistically significant differences occurred between groups 3,4 and 5 who received hypercaloric diet. Group 5 of rats treated only with hypercaloric diet showed a statistically decreased levels of TAC compared with groups 3 and 4 at hepatic level (Table 1). The hypercaloric diet given daily by gavage leads to ROS formation that will be neutralized efficiently by vitamin $E$ and lutein.

At spleen level we obtained in group 1 an increased statistically insignificant level for TAC versus group 2 . The group 4 of Wistar rats treated with hypercaloric diet and a daily dose of PLGA-lutein presented an increased level for TAC but statistically insignificant versus group 5. TAC levels was increased and statistically significant in group 3 who received PLGA-vitamin E compared with group 5.

\section{Conclusions}

A diet rich in lipids and carbohydrates leads to the installation of OS in many organs such as the liver and the spleen. The antioxidant effects of vitamin $\mathrm{E}$ and lutein are greatly enhanced by their entrapment in the PLGA structure. The daily administration of PLGA-vitamin E or PLGA-lutein improve liver and spleen redox status. PLGA nanoparticles can be successfully used as carriers for numerous therapeutic agents in the treatment of many systemic diseases associated with OS.

\section{References}

1.*** World Health Organization, 2018.

2.TUMMINIA, A., VINCIGUERRA, F., PARISI, M., GRAZIANO, M., SCIACCA, L., BARATTA, R., FRITTITTA, L., Int J Mol SCi, 20, no 12, 2019, p.E2863. 
3.YOUNOSSI, Z.M., KOENIG, A.B., ABDELATIF, D., FAZEL, Y., HENRY, L., WYMER, M., Hepatology, 64, no1, 2015, p. 73-84.

4.RANGEL HUERTA, O.D., PASTOR VILLAESCUSA, B., GIL A., Metabolomics, 15, no 6, 2019, p.93.

5.WONG, S.K., CHIN, K.Y., SUHAIMI, F.H., AHMAD, F., NIRWANA, I., Frontiers in pharmacology, 8, 2017, 444.

6.BALABAN,M., VIRGOLICI,B., DINU,A., TOTAN, A., MIRICESCU, D., STEFAN,D.,GREABU,M., MOHORA, M.,. Rev Cim., (Bucharest),70, no. 4, 2019, p.1315-1318.

7.CARO-SABIDO, EA., LARROSA-HARO, A., Rev Gastroenterol Mex, 84, no 2, 2019, p.185-194.

8.BLAKELY, S., HERBERT, A., COLLINS, M., JENKINS, M, MITCHELL, G., GRUNDEL, E., O'NEILL, K.R., KHACHIK, F., J Nutr,133, no 9, 2003, p.2838-44.

9.KABAT, G.C., HEO, M., OCHS-BALCOM, H.M., LE BOFF, M.S., MOSSAVAR-RAHMANI,Y.,, ADAMS-CAMPBELL, LL., NASSIR, R., ARD, J., ZASLAVSKY, O., ROHAN, T.E., Eur J Clin Nutr,70, no 1, 2016, p.47-53.

10.CAI, J., QIAN, K., ZUO, X, YUE, W., BIAN, Y., YANG, J., WEI, J., ZHAO, W., QIAN, H., LIU, B., J Biomater Appl,33, no 10, 2019, p.394-1406.

11.MIRICESCU, D., STANESCU, I., PERLEA, P., CALENIC, B., RADULESCU, R., TOTAN, A., VIRGOLICI, B., SABLIOV, C., GREABU, M, Mat. Plast., 54, no 2, 2017, p.249-252.

12. OGUNTIBEJU, 0.0., Int J Physiol Pathophysiol Pharmacol,15, no 11,2019, p.45-63.

13.EVANS, J.L., GOLFINE, I.D., MADDUX, B.A., GRODSKY, G.M., Endocr Rev, 23, 2002, p599-622.

14.ARRONSON, D., RAYFIELD, E.J ., Cardiovasc Diabetol, 1, 2002, p.110.

15.SFARTI, C.V., CIOBICA,A., STANCIU, C.,BALAN, G.G., GARLEANU,I., TRIFAN, A., Rev Chim. (Bucharest), 69, no. 8 ,2018, p, 2172-2176.

16.DAVI, G., GUAGNANO, M.T., CIABATTONI, G., BASILI, S., FALCO, A., MARINOPICCOLI, M., Jama, 288, 2002, p, 2008-2014.

17.GUAL-GRAU, A., GUIRRO, M., MAYNERIS-PERXACHS, J ., AROLA, L., BOQUE, N., J Nutr Biochem, 21, no 71, p.122-131.

18.Woo, M., Han, S.,, Song, Y.O., Prev Nutr Food Sci,24,no 2, 2019, p.114-120.

19.INOGUCHI, T., LI, P., UMEDA, F., YU, H.Y., KAKIMOTO, M., IMAMURA, M., Diabetes, 49, 2000, p. 1939-1945.
20.RODRIGUEZ-PORCEL, M., LERMAN, L.O., HOLMES, JR D.R., RICHARDSON, D., NAPOLI, C., LERMAN, A., Cardiovasc Res, 53, 2002; p. 1010-1018

21.LYON, C.J., LAW., R.E., HSUEH, W.A., Endocrinology, 144, 2003; p. 2195-2200.

22.DOBRIAN, A.D., DAVIES, M.J., PREWITT, R.L., LAUTERIO, T.J ., Hypertension, 35, 2000; p.1009-1015

23.OLUSI, S.O., Int J Obes Relat Metab Disord,26, 2002,p. 1159-1164. 24.CASARIU,D.E.,VIRGOLICI, B.,GREABU, M., TOTAN,A., MIRICESCU, D., MITREA, N., ION, A., MOHORA,M., Farmacia,59, no 4, 2011, p. 471482.

25.POPESCU, L.A.,VIRGOLICI, B., STEFAN, D.,LIXANDRU,D., TIMNEA, O.,VIRGOLICI H., SINESCU, C.,MOHORA, M.,Rev Chim, 68, no. 4, 2017, p.758-782.

26.SAITO, I., YONEMASU, K., INAMI, F., Circ J,67, 2003,p. 323-329.

27.WEYER, C., YUDKIN, J.S., STEHOUWER, C.D., SCHALKWIJK, C.G., PRATLEY, R.E., TATARANNI, P.A., Atherosclerosis,161, 2002, p. 233242.

28.PETELIN, A., KENIG, S., KOPINE, R., DEZELAK, M., BIZJAK, M.C., PRAZNIKAR Z.J., Evid Based Complement Alternat Med,13, 2019, p. $1-11$.

29.MANNA, P., J AIN, S.K.; Metab Syndr Relat Disord,13, no 10, 2015, p.423-44.

30.NEUHOUSER, M.L., CHERYL, C.L.R., ELDRIDGE, A. L., KRISTAL, A.R., PATTERSON, R.E., COOPER,D.A., SZTAINER,D.N., CHESKIN L.C., Thornquist,M.D., Nutrit J,131, no 8, 2001, p. 2184-2191.

31.WALEED, H. A., World J Clin Pediatr, 8, no1, 2014, p. 6-13.

32.LEE, Y., HU, S., PARK, Y.K., LEE, J.Y., Rev Nutr Food Sci, 24, no 2, 2019, p.103-113.

33.NAVARRO, S.M., MORGAN, T.W., ASTETE, C.E.,STOUT, R.W., COULON, D., MOTTRAM, P., SABLIOV, C.M., Nanomedicine (Lond), 11, no 13, 2016, p.1653-69.

34.XING, Y., SHI, S., ZHANG, Y., LIU, F., ZHU, L., SHI, B., WANG, J., Mol Med Rep, 10434, 2019.

35.RADULESCU,C., MIRICESCU,D., CALENIC,B., RADULESCU,R., STANESCU, I.I.,CALENIC, A., TOTAN, A., VIRGOLICI,B., BALAN,D., GREABU, M.,Mat. Plast., 55, no.3,2018, p. 291-294.

36.MIRICESCU, D., BALAN, D.G., RADULESCU,C., RADULESCU,R., STANESCU,I.I., MOHORA,M., VIRGOLICI,B., TOTAN,A., GREABU, M.,Mat. Plast., 56, no. 2, 2019, p.337-340.

37.TOTAN,A., BALAN,D.G., MIRICESCU,D., RADULESCU,R., STANESCU,I.I., VIRGOLICI, B., MOHORA,M., GREABU,M., Rev Chim. (Bucharest), 70, no. 1,2019, p. 78-83.

Manuscript received:13.08.2019 